\title{
Comparison of Ultrasonographic Estimated Fetal Weight and Actual Birthweight Performed by Residents in Training at the University Hospital of the West Indies
}

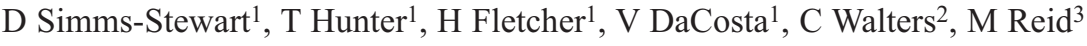

\begin{abstract}
Objective: To determine the correlation of ultrasonographic estimation of fetal weight and actual birthweight and the impact of the level of resident's training on the results.

Methods : This was a prospective study of 90 women with term pregnancies. Ultrasound estimated fetal weight (EFW) was calculated by a pre-programmed Hadlock formula. Days from ultrasound to delivery were less than seven. The EFW was compared to the actual birthweight at delivery. The year of training of the resident that performed the ultrasound was recorded. Exclusion criteria included diabetes mellitus and known fetal anomalies.

Results: Mean age was 28 years, parity was 0 to 4 and mean gestational age was 38 weeks. There was an average over-estimation of 64.8 grams. The difference between mean EFW and mean birthweight was not significant $(\mathrm{p}=0.067)$. The difference between mean EFW and mean birthweight when calculated according to year of residency was not significant, $\mathrm{p}=0.075$ and 0.402 for junior and senior residents, respectively.

Conclusion: There is good correlation between residents' ultrasonographic estimation of fetal weight and actual birthweight at the University Hospital of the West Indies. There was no significant difference in correlation between senior and junior residents. Developments in computer technology might contribute to decrease in the learning curve.
\end{abstract}

Keywords: Fetal weight, residents training, ultrasound, University Hospital, West Indies

\section{Comparación del Peso Fetal Estimado por Ultrasonografía y el Peso Real al Nacer Realizada por los Residentes en Formación en el Hospital Universitario de West Indies}

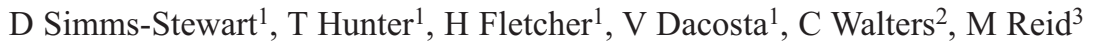

\begin{abstract}
RESUMEN
Objetivo: Determinar la correlación de la estimación ultrasonográfica del peso fetal y el peso real al nacer, y el impacto del nivel de formación del residente en los resultados.

Métodos: Se trató de un estudio prospectivo de 90 mujeres con embarazos a término. El peso fetal estimado (PFE) por ultrasonido fue calculado mediante una fórmula de Hadlock preprogramada. Los días transcurridos desde el ultrasonido hasta el parto fueron menos de siete. Se comparó el PFE con el peso real en el parto. Se registró el año de formación del residente que realizó el ultrasonido. Los criterios de exclusión criterios incluyeron diabetes mellitus y anomalías fetales conocidas.

Resultados: La edad promedio fue 28 años; la paridad fue de 0 a 4; la edad gestacional fue de 38 semanas. Hubo una sobreestimación promedio de 64.8 gramos. La diferencia entre el PFE promedio y el peso promedio al nacer no fue significativa $(\mathrm{p}=0.067)$. La diferencia entre el PFE promedio y el peso promedio al nacer calculada según el año de residencia no fue significativa, siendo $\mathrm{p}=0.075 y$ 0.402 para médicos en la primera y última etapa de su residencia, respectivamente.

Conclusión: Existe una buena correlación entre la estimación ultrasonográfica del peso fetal, realizada por los residentes, y el peso real al nacer en el Hospital Universitario de West Indies. No hubo ninguna
\end{abstract}

From: ${ }^{1}$ Department of Obstetrics and Gynaecology, ${ }^{2}$ Dean's Office, Faculty of Medical Sciences and ${ }^{3}$ Tropical Metabolism Research Unit, Tropical Medicine Research Institute, The University of the West Indies, Kingston 7, Jamaica

West Indian Med J 2013; 62 (9): 831
Correspondence: Dr D Simms-Stewart, Department of Obstetrics and Gynaecology, The University of the West Indies, Kingston 7, Jamaica. E-mail: donnette_stewart@hotmail.com 
diferencia significativa en la correlación entre los residentes en sus primeras y últimas etapas. Los desarrollos en la tecnología informática pueden contribuir a la disminución de la curva de aprendizaje.

Palabras claves: Peso fetal, residentes en formación, ultrasonido, Hospital Universitario de West Indies

West Indian Med J 2013; 62 (9): 832

\section{INTRODUCTION}

The clinical estimation of fetal weight is a technique used by caregivers of pregnant women to try to determine if the baby is too large, too small, or appropriate for gestational age. Ultrasonographic estimation of fetal weight has been used for decades and the principle of this is that the sonographic measurements of multiple linear and planar dimensions of the fetus provide sufficient parametric information to allow for accurate algorithmic reconstruction of the three-dimensional fetal volume of varying tissue density. Various formulae have been used ultrasonographically to assess fetal weight estimation. The Hadlock formula is pre-programmed in the ultrasound machine used in our department. This uses the fetal bi-parietal diameter, the fetal abdominal circumference and the fetal femoral length in the equation to estimate the fetal weight. This formula has been shown to be most predictive in studies $(1,2)$.

Birthweight is strongly associated with perinatal outcome. The perinatal complications associated with low birthweight are attributable to preterm delivery, intrauterine growth restriction (IUGR), or both. Macrosomic infants are at risk of shoulder dystocia and brachial plexus injury during labour (3). These infants are more likely to undergo operative vaginal delivery and Caesarean delivery. These complications may be potentially limited by an accurate estimation of the fetal weight at term, which may facilitate a planned and safe delivery.

At the University Hospital of the West Indies (UHWI), the estimation of fetal weight by ultrasonography is carried out on a daily basis and this information is used to make important management decisions. The ultrasonography is usually carried out by a resident in training, year two to five of residency (the fifth year being the final year of the Doctor of Medicine programme). These residents are taught the techniques of estimating fetal weight by a consultant fetomaternal specialist. The correlation of estimated fetal weight to actual birthweight, in this hospital, was tested by a previous unpublished study. The sample size was, however, small.

\section{Aim}

This study aimed to determine the correlation of ultrasonographic estimation of fetal weight done by residents at the UHWI with actual birthweight and to determine the impact of the level of training on this correlation.

\section{SUBJECTS AND METHOD}

A prospective study of 90 term pregnancies delivered at the UHWI between January 2009 and January 2010 was carried out. Subjects were randomly chosen and those who delivered within seven days of the ultrasound date were included in the study. The gestational age of the pregnancies varied from 33 weeks to 40 weeks. Ultrasound assessment (GE Medical Volusion $730^{\circledR} 2005$ ) of fetal weight was done by standard fetal biometric measurement of fetal parameters using the Hadlock formula. The estimated fetal weight was subsequently compared to the actual birthweight taken from the labour ward records or the patient's record. The year of training of the resident that performed the ultrasound was also recorded. Patients were excluded if there was a history of diabetes mellitus or if they were in labour or known to have fetal anomalies. Bland-Altman analysis was used to assess limits of agreement.

\section{RESULTS}

The total number of participants was 90 pregnant women, with the estimated fetal weight and the actual birthweight recorded for 89 women. The mean age of the patients was 28 years. The gravidity ranged from one to seven, and the parity ranged from zero to four, with $53 \%$ of the patients being nulliparous. The gestational age of the participants ranged from 33 to 41 weeks, with the mean at 38 weeks gestation.

The year of residency of the ultrasonographers ranged from the second to the fifth year. There were varied indications for these ultrasound scans, the most common being fetal assessment (biophysical profile) and/or estimated fetal weight prior to delivery by induction of labour. Body mass index (BMI) was calculated from the booking weight and height. It was noted that $22.2 \%$ of the patients were obese $(\mathrm{BMI}>30)$ and $70.4 \%$ of patients had normal BMI (18.524.9).

The number of days to delivery ranged from zero to seven days. Thirty-seven per cent of patients were delivered within one day of having ultrasound done with less than five per cent being delivered five or more days after ultrasound.

The weight difference (weight dif) was calculated as estimated fetal weight (EFW) - birthweight (BWT). There was an average over-estimation of 64.8 grams (Table 1). However, the difference between mean EFW and mean BWT was not significant $(p=0.067)$ based on a two-sided paired $t$ test. 
Table 1: Difference between mean estimated fetal weight and mean actual birthweight

\begin{tabular}{llcc}
\hline Variable & Mean & Standard deviation & Range \\
\hline Estimated fetal weight $(\mathrm{g})$ & 3267.798 & 520.0698 & $1627-4584$ \\
Actual birthweight $(\mathrm{g})$ & 3202 & 547.8918 & $1590-4580$ \\
Weight difference $(\mathrm{g})$ & 64.83146 & 329.3892 & $-1099-766$ \\
\hline
\end{tabular}

The difference between mean EFW and mean BWT when calculated according to year of residency was not significant, $p=0.075$ and 0.402 for junior and senior residents, respectively (Table 2 ).

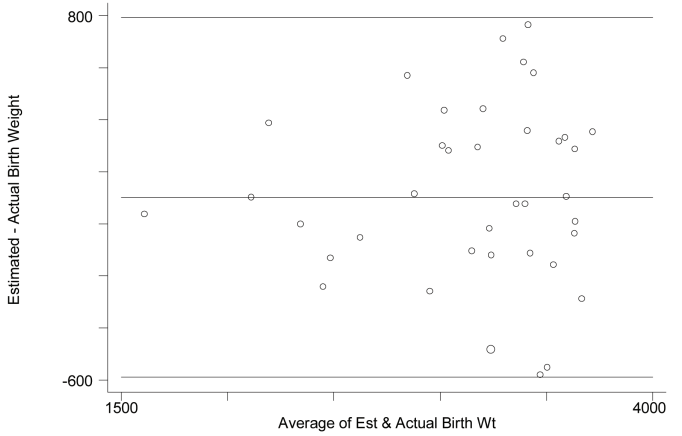

Fig. 2: Difference between estimated fetal weight and actual birthweight versus the average of the weights for junior residents. $95 \%$ limits of agreement $=-589.533$ to $792.302 ;$ Mean difference $=$ 101.385 (CI $-10.600,213.369)$; range of average values $=1608.500$ to 3717.000

Table 2: Weight difference according to resident level

\begin{tabular}{lccccc}
\hline $\begin{array}{l}\text { Year of } \\
\text { residency }\end{array}$ & $\begin{array}{c}\text { Age } \\
\text { (years) }\end{array}$ & \multicolumn{1}{c}{$\begin{array}{c}\text { Estimated } \\
\text { fetal weight } \\
(\mathbf{g})\end{array}$} & $\begin{array}{c}\text { Actual } \\
\text { birthweight } \\
(\mathbf{g})\end{array}$ & $\begin{array}{c}\text { Weight } \\
\text { difference } \\
\text { (g) }\end{array}$ & $\begin{array}{c}\text { Ultrasound to } \\
\text { delivery days }\end{array}$ \\
\hline $2^{\text {nd }}-3^{\text {rd }}$ & $28.7 \pm 6.2$ & $3196.6 \pm 526.8$ & $3095.2 \pm 516.9$ & $101.4 \pm 345.5$ & $2.3 \pm 1.9$ \\
$4^{\text {th }}-5^{\text {th }}$ & $27.65 \pm 5.8$ & $3387.96 \pm 481.1$ & $3334.6 \pm 541.7$ & $42.3 \pm 331.5$ & $2.2 \pm 1.88$ \\
\hline
\end{tabular}

The variability in the difference between EFW and BWT for all residents was fairly consistent, although it seemed to peak where the average weight measurement was $3500 \mathrm{~g}$ (Fig. 1). Among junior residents, the difference

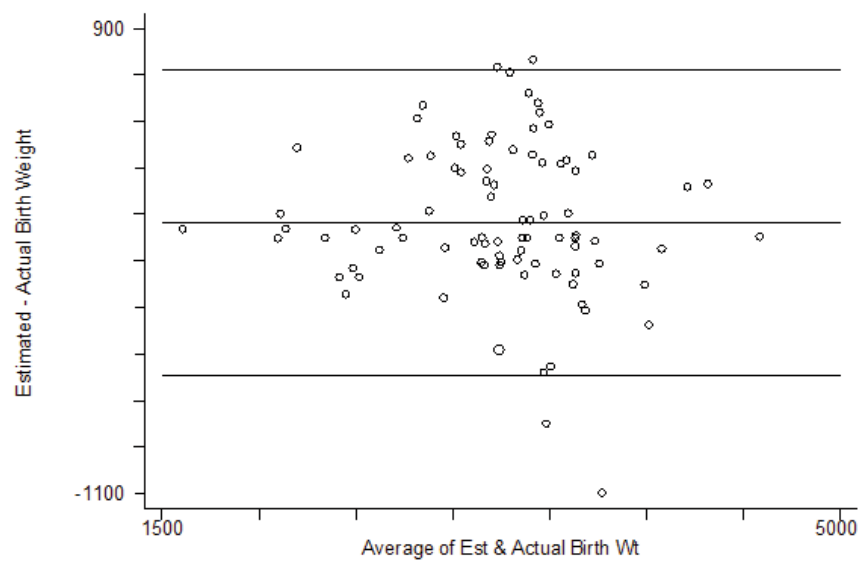

Fig. 1: Difference between estimated fetal weight and actual birthweight versus the average of the weights for all residents. $95 \%$ limits of agreement $=-593.947$ to 723.610 ; mean difference $=$ $64.831(\mathrm{CI}-4.555,134.218)$; range of average values $=1608.500$ to 4582.000 .

between EFW and BWT tended to increase as the average weight increased, suggesting larger discrepancies for heavier babies (Fig. 2).

The variability in the difference between EFW and BWT was fairly consistent among senior residents (Fig. 3).

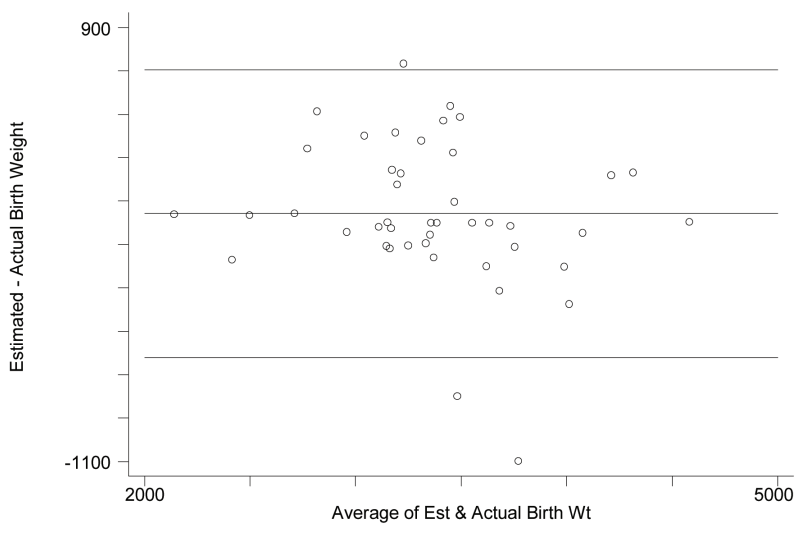

Fig. 3: Difference between estimated fetal weight and actual birthweight versus the average of the weights for senior residents. $95 \%$ limits of agreement $=-620.678$ to 705.314 ; mean difference $=$ 42.318 (CI -58.466, 143.103); range of average values $=2139.000$ to 4582.000 .

\section{DISCUSSION}

Currently available methods for assessing fetal weight in utero are subject to predictive errors. These methods include tactile assessment of fetal size by the obstetrician or midwife, maternal self-estimation and obstetric ultrasonography. Tactile assessment of fetal size is a recognized method of fetal weight estimation (4). Measurement of symphysio-fundal height has been shown to be highly predictive of fetal weight (5). This is, however, subjective as it is both patient- and clinician-dependent for its success (less accurate for obese than non-obese gravidas). 
Maternal self-estimation by multiparous women in one study has shown comparable accuracy to clinical palpation for predicting birthweight (6). Other methods have been utilized such as birthweight prediction equations and estimation of birthweight based on clinical risk factors as well as the use of an algorithm derived from maternal and pregnancy specific characteristics.

Obstetric ultrasonography is the most modern method for assessing fetal weight and involves the use of fetal measurements in a pre-programmed equation. The advantage of this technique is that it relies on linear and/or planar measurement of in-utero fetal dimensions that are definable objectively and should be reproducible.

Limiting factors associated with the ultrasonographic prediction of fetal weight include imprecise imaging of fetal structures (due to limitations such as patient obesity, placentation, oligohydramnios, and/or fetal position), unavoidable operator- and equipment-related measurement errors and approximations. It may be useful to take these factors into account and examine how they affected the fetal weight estimation.

It is important for institutions to assess the accuracy of estimation of fetal weight in their unit as this information is useful in making important clinical decisions such as route and timing of delivery. There is no previous published data with this information from our institution.

The time between ultrasound estimation of fetal weight and actual delivery impacts on the correlation of actual and estimated weight, with one to three days being associated with better correlation (5). Thirty-seven per cent of patients were delivered within one day of having ultrasound done; less than five per cent were delivered five or more days after ultrasound. There was an average over-estimation of fetal weight of 64.8 grams which was not significant $(p=0.067)$. Therefore, ultrasounds done for estimation of fetal weight by the residents in training at the UHWI correlated well with actual birthweight.

It was noted that the more experienced residents obtained EFW measurements closer to the actual birthweight. The calculated difference in the accuracy of estimating birthweight ultrasonographically between senior and junior residents was, however, not significant. Previous studies have shown that there is a learning curve for ultrasonographic estimates of fetal weight, with a significant decrease in the per cent error seen with advancing training among residents, reaching acceptable levels of more than $70 \%$ of estimates within $10 \%$ of birthweight after 24 months of ultrasonographic experience (8).

The ultrasound scans performed by residents in the Department of Obstetrics and Gynaecology at The University of the West Indies give estimation of fetal weights that are comparable to the birthweight within a reasonable margin of error. Additionally, the EFW obtained by more experienced residents was closer to the actual birthweight when compared to less experienced residents; however, this was not statistically significant and should not affect the clinical outcome. The learning curve appears to be flattening as demonstrated by the lack of difference between residents. This may be due to the increased use of computer technology.

In conclusion, the training and experience provided at the UHWI for the residents to perform ultrasounds estimating fetal weights is adequate and useful in directing management. The year of residency training did not make a difference, with the learning curve appearing to be flattening.

\section{REFERENCES}

1. Zayed F, Abu-Heija A. A comparison between ultrasound and clinical methods for predicting fetal weight. J Obstet Gynaecol 1999; 19: 159-61.

2. Bhandary A, Pinto P, Shetty A. Comparative studies of various methods of fetal weight estimation at term pregnancy. J Obstet Gynecol Ind 2004; 54: 336-9.

3. Wilcox AJ, Skjaerven R. Birth weight and perinatal mortality: the effect of gestational age. Am J Public Health 1992; 82: 378-82.

4. Bossak WS, Spellacy WN. Accuracy of estimating fetal weight by abdominal palpation. J Reprod Med 1972; 9: 58-60.

5. Dare FO, Ademowore AS, Ifaturoti OO, Nganwuchu A. The value of symphysiofundal height/abdominal girth measurement in predicting fetal weight. Int J Gynaecol Obstet 1990; 31: 243-8.

6. Herrero RL, Fitzsimmons J. Estimated fetal weight. Maternal vs. physician estimate. J Reprod Med 1999; 44: 674-8.

7. Ben-Haroush A, Yogev Y, Mashiach R, Hod M, Meisner I. Accuracy of sonographic estimation of fetal weight before induction of labour in diabetic pregnancies and pregnancies with suspected fetal macrosomia. J Perinat Med 2003; 31: 225-30.

8. Predanic M, Cho A, Ingrid F, Pellettieri J. Ultrasonographic estimation of fetal weight: acquiring accuracy in residency. J Ultrasound Med 2002; 21: 495-500. 